\title{
Landmark-based Morphometric and Meristic Analysis of Serranidae
}

\author{
Sang Gu Lim ${ }^{1}$, Min Hwan Jeong ${ }^{1}$, Bong Seok Kim ${ }^{1}$, Tae Ho Lee ${ }^{2}$, Hyun Woo Gil ${ }^{2}$ and ${ }^{\dagger}$ In-Seok Park ${ }^{2}$ \\ ${ }^{1}$ Future Aquaculture Research Center, National Fisheries Research \& Development Institute, Jeju 690-192, Korea \\ ${ }^{2}$ Division of Marine Bioscience, College of Ocean Science and Technology, Korea Maritime and Ocean University,
} Busan 606-791, Korea

\begin{abstract}
The landmark-based morphometric and meristic analysis of the kelp grouper (Epinephelus bruneus), red spotted grouper (E. akaara) and seven-banded grouper (E. septemfasciatus) were performed to compare the differentiation of overall body shape and structure. The measurements of the morphometric dimensions were observed in 25 parts (truss dimension: 16 parts; head part dimension: 9 parts) of 38 morphometric dimensions and also meristic differences observed in 3 parts (dorsal fin, anal fin and caudal fin) of 6 meristic counts $(P<0.05)$. Observed morphometric characteristics primarily involved in truss and head part dimension, kelp grouper have larger values in caudal part of truss dimension, kelp grouper, red spotted grouper and seven-banded grouper have similar values in pectoral part of truss dimension, in addition to, results of head part dimension showed that red spotted grouper have smaller values in overall dimensions $(P<0.05)$. As meristic characteristics, kelp grouper have more number of anal fin rays than other fish, red spotted grouper have more number of dorsal soft rays than other fish, and seven spotted grouper have more number of anal soft rays, and caudal fin rays than other fish $(P<0.05)$. Photographed under the x-ray, kelp grouper have the most curved vertebral column and largest swim bladder than other fishes $(P<0.05)$. Our results of this study confirmed that 3 subfamily fishes adequately can distinguish with external body shape, and we hope that the results of our study could be used to identify in Serranidae family as taxonomical parameters.
\end{abstract}

Key words : Landmark-based morphometric, Meristic, Morphology, Serranidae

\section{INTRODUCTION}

Research of reliable classification and discrimination of similar fish species require more accurately advanced information than previously studied results. Development, maturation and modification of body shape were influenced by a mixture of diversely environmental situation and genetic factors, but they are not fully restricted to environmental factors and hereditary characteristics, and those were create a variety of body shapes within a species (Straüss \& Bond, 1990).
Fish population have been sampled in order to distinguish and discriminate the body structure, biological body shape as well as living organ and to determine the morphological differentiation and variation for using morphometric and meristic of fish population (Straüss \& Bookstein, 1982; Melvin et al., 1992; Park et al., 2001).

Morphometric analysis has been used to identify the uncertain hybrids, unidentified species, and modification of fish population (Straüss \& Bookstein, 1982; Park et al., 2003, 2012; Turan et al., 2006). Morphometric network measure-

\footnotetext{
Manuscript received March 20, 2016, Received in revised form March 27, 2016, Accepted April 01, 2016

${ }^{\dagger}$ Corresponding Author : In-Seok Park, Division of Marine Bioscience, College of Ocean Science and Technology, Korea Maritime and Ocean University, 727 Taejong-ro, Yeong do-gu, Busan 606-791, Korea. Tel. : +82-51-410-4321, Fax : +82-51-404-4750, E-mail : ispark@kmou.ac.kr

This is an Open Access article distributed under the terms of the Creative Commons Attribution Non-Commercial License (http:// creativecommons.org/licenses/by-nc/3.0) which permits unrestricted non-commercial use, distribution, and reproduction in any medium, provided the original work is properly cited.
} 
ments showed that they are composed of a number of digitized landmark-based points and they executed useful tools for identifying the complex and similar stock identification (Barlow, 1961; Ihssen et al., 1981; Straüss \& Bookstein, 1982; Templeman, 1983). Digitized landmarks are a point of correspondence on an external organ that identically matches in fish populations (Barlow, 1961; Bookstein, 1991).

Classical dimensions have commonly been assessed in studies of the morphometric characteristics of fish bodies, and are focused on characteristics of the body length, depth, and width, (Straüss \& Bond, 1990; Park et al., 2001, 2003, 2012). Truss network system was composed of interconnected distances between various digitized landmarks, which was constructed the anatomical network in body shape (Straüss \& Bookstein, 1982). Pointed landmarks in classical, truss and head part dimension selected the representative feature of fish which help more understandable to the analysis of morphometric dimension.

Meristic characteristics are also influenced by environmental conditions (Lindsey, 1988; Saima \& Onkar, 2015), which were serially repeated, countable structures and compared the fin rays (spinous ray and soft ray), vertebrae, gill rakers and lateral lines, respectively (Melvin et al., 1992; Hurlbut \& Clay, 1998; Nakamura, 2003; Turan et al., 2006).

Groupers are widely distributed in the tropical and subtropical waters from Southeast Asian countries, including Korea's Jeju Island, China, and Southern parts of Japan (Brais, 1987; Fukuhara, 1989; Heemstra \& Randall, 1993). The marine teleost fish groupers, protogynous hermaphrodite, are change their sex reversal from female to male and economically important species because of lucrative price, high market value, high consumer demand and desirable taste (Brais, 1987; Fukuhara, 1989; Li et al., 2004). In recent years, overfishing in Jeju coastal waters and mass mortality of Serranidae fishes from viral-based disease has led grouper resources to rapidly decreased. Low survival rate of juvenile groupers is needed to more research, in Korea, only a few fish farms are trying seven-banded grouper seeding production.

The kelp grouper (Epinephelus bruneus), red spotted grouper (E. akaara) and seven-banded grouper (E. septemfasciatus) a species of fish in order, Perciformes and the Family, Serranidae (Brais, 1987). Kelp grouper is a carnivorous and dark brown pattern fish that can be found in sub-tropical waters from shallow coastal regions (Park et al., 2008) and registered in vulnerable species, International Union for Conservation of Nature (IUCN) (Brais, 1987; Heemstra \& Randall, 1993). Red spotted grouper is a reef fish and inhabited in tropical and sub-tropical regions of Southeast Asia, especially found in the China and Southern parts of Korea, which have early life history (Ukawa et al., 1966) and also registered in endangered species, IUCN (Brais, 1987; Heemstra \& Randall, 1993). Seven-banded grouper inhabited in shallow waters around Japan, China and Korea and registered in attention necessity species, IUCN (Brais, 1987; Heemstra \& Randall, 1993).

Previous researches on the Serranidae fishes have been conducted as followed; temperature effects in egg development and hatching of kelp grouper (Yang et al., 2007), development of microsatellite markers for the kelp grouper (Kang et al., 2013). Seven-banded grouper has been conducted as followed: reproductive biology of the seven-banded grouper (Kim et al., 1997), induced sex reveal of sevenbanded grouper (Song et al., 2005), induction of maturation and ovulation (Song et al., 2008).

Despite these research studied, not yet, industrialization of aquaculture and seeding production had been attempting to continue. Also, defining differences by morphological characters to compare family in fish has not been conducted. Therefore, our main objective of study is to define morphological characters of kelp grouper, red-spotted grouper and seven-banded grouper by using morphological analysis as well as X-ray for observing interior side of the groupers. 


\section{MATERIALS AND METHODS}

\section{Experimental fish}

The kelp grouper, Epinephelus bruneus, red spotted grouper, E. akaara and seven-banded grouper, E. septemfasciatus were obtained from Future Aquaculture Research Center (FARS), National Fisheries \& Development Institute (NFRDI) in Jeju Island, Korea. Fishes were quickly frozen and transported to aquaculture facility at the Fishery Genetics and Breeding Sciences Laboratory of the Korea Maritime and Ocean University in Busan, Korea.

In total, 50 specimens of each species were defrosted before to use for the morphometric and meristic analysis and performed in triplicate repetition, respectively. Prior to morphological measurements, Total length (TL) and body weight $(\mathrm{BW})$ were measured to the nearest $0.1 \mathrm{~g}$ and 0.1 cm using electric balance (AX 200, Shimadzu Corp., Japan) and digital vernier calipers (CD-20 CP; Mitutoyo, Japan), respectively. The TL and BW of each species were $39.7 \pm 2.38$ $\mathrm{cm}$ and $1,342 \pm 79.3 \mathrm{~g}$ in kelp grouper, $38.4 \pm 2.43 \mathrm{~cm}$ and $1,213 \pm 87.4 \mathrm{~g}$ in red spotted grouper, $36.6 \pm 3.03 \mathrm{~cm}$ and $1,157 \pm 81.7 \mathrm{~g}$ in seven-banded grouper, respectively. We used the camera for comparison of coloring among the 3 fishes, digital images of each species were taken by digital camera (Coolpix 4500, Nikon, Japan).

\section{Landmark-based morphometric analysis}

The kelp grouper, red spotted grouper and seven-banded grouper were measured by geometric morphometric methods of Bookstein (1991) and Park et al. (2001). The multivariately linear dimensions in pictures of Figs. 1, 2 and 3 were taken to the nearest $0.1 \mathrm{~cm}$ using digital vernier calipers (CD20CP; Mitytoyo, Kawasaki, Japan) for each species. To analyze the morphometric differentiation in classical dimension (CD), truss dimension (TD) and head part dimension (HD), in total (Table 1 and Fig. 1), 38 landmark distances and 24 coefficients were pointed and digitized; 6 distances and 8 coefficients in the CD, 21 and 11 in the TD, and 11 and 5 in the HD, respectively. The measured results of $\mathrm{CD}$ dimensions and TD dimensions were divided into distance of standard length $1 \times 4(S L)$. Following, horizontal and transversal CD landmarks complied with convergent morphotypes and distributed to 6 portion, $1 \times \mathbf{2}$ : most anterior extension of the head $(\mathrm{MAEH})$ to origin of dorsal fin base; $\mathbf{1} \times \mathbf{3}$ : MAEH to origin of caudal fin base; $\mathbf{1} \times \mathbf{5}$ : MAEH to origin of anal fin base; 1×6: MAEH to origin of ventral fin base; $1 \times 7$ : MAEH to origin of pectoral fin base and $\mathbf{1} \times \mathbf{8}$ : MAEH to operculum.

Also following truss network TD landmarks distributed to 21 portion, $1 \times 2$ : origin of dorsal fin base (ODFB) to insertion of dorsal fin base (IDFB); $\mathbf{1} \times \mathbf{6}$ : ODFB to origin of anal fin base (OAFB); 1×7: ODFB to origin of ventral fin base (OVFB); 1×9: ODFB to origin of pectoral fin base $(\mathrm{OPFB}) ; \mathbf{1} \times \mathbf{1 1}$ : ODFB to posterior aspect of operculum (PAO); $\mathbf{2} \times \mathbf{3}$ : insertion of dorsal fin base (IDFB) to origin of above caudal fin base (OACFB); $2 \times 4$ : IDFB to origin of bottom caudal fin base (OBCFB); $\mathbf{2} \times \mathbf{5}$ : IDFB to insertion of anal fin base (IAFB); $\mathbf{3} \times \mathbf{4}$ : $\mathrm{OACFB}$ to $\mathrm{OBCFB} ; \mathbf{3} \times \mathbf{5}$ : OACFB to IAFB; $\mathbf{3} \times \mathbf{6}$ : $\mathrm{OACFB}$ to OAFB; $\mathbf{4} \times \mathbf{5}$ : OBCFB to IAFB; $\mathbf{5} \times \mathbf{6}$ : IAFB to OAFB; $\mathbf{6} \times 7$ : OAFB to OVFB; $\mathbf{6} \times \mathbf{9}$ : OAFB to OPFB; $\mathbf{6} \times \mathbf{1 1}$ : OAFB to PAO; $7 \times \mathbf{8}$ : OVFB to insertion of ventral fin base (IVFB); 7×9: OVFB to OPFB; $7 \times \mathbf{1 1 : ~ O V F B ~ t o ~ P A O ; ~} 9 \times \mathbf{1 0}$ : OPFB to PAO; and $\mathbf{9 \times 1 1}$ : OPFB to PAO.

The HD dimensions divided into distance of head length $1 \times 4(H L)$. Intensively closed to head parts, HD landmarks distributed to 11 portions, the measured results of HD landmarks were divided into distance of head length $1 \times \mathbf{4}$ $(H L) . \mathbf{1} \times \mathbf{2}$ : MAEH to above of nostril $(\mathrm{AN})$; $\mathbf{1} \times \mathbf{3}$ : MAEH to above of eye $(\mathrm{AE}) ; \mathbf{1} \times \mathbf{5}$ : MAEH to posterior aspect of snout $(\mathrm{PAS}) ; \mathbf{2} \times \mathbf{3}$ : $\mathrm{AN}$ to $\mathrm{AE} ; \mathbf{2} \times \mathbf{4}$ : $\mathrm{AN}$ to posterior aspect of operculum $(\mathrm{PAO}) ; \mathbf{2} \times \mathbf{5}$ : $\mathrm{AN}$ to $\mathrm{PAS} ; \mathbf{3} \times \mathbf{4}$ : $\mathrm{AE}$ to $\mathrm{PAO}$; 3×5: AE to PAS; 4×5: PAO to PAS; eye diameter (ED) and interorbital width (IW).

\section{Meristic counts}

The kelp grouper, red spotted grouper and seven-banded grouper of meristic counts were compared and analyzed. 
Table 1. Dimensions of body shape for kelp grouper (Epinephelus bruneus), red spotted grouper (E. akaara) and seven-banded grouper ( $E$. septemfasciatus)

\section{Classical dimension}

\begin{tabular}{|c|c|}
\hline Standard length $(S L)$ & $1 \times 4$ \\
\hline Most anterior extension of the head - origin of dorsal fin base & $1 \times 2$ \\
\hline Most anterior extension of the head - origin of above caudal fin base & $1 \times 3$ \\
\hline Most anterior extension of the head - origin of anal fin base & $1 \times 5$ \\
\hline Most anterior extension of the head - origin of ventral fin base & $1 \times 6$ \\
\hline Most anterior extension of the head - origin of pectoral fin base & $1 \times 7$ \\
\hline Most anterior extension of the head - posterior aspect of operculum & $1 \times 8$ \\
\hline \multicolumn{2}{|l|}{ Truss dimension } \\
\hline Origin of dorsal fin base - insertion of dorsal fin base & $1 \times 2$ \\
\hline Origin of dorsal fin base - origin of anal fin base & $1 \times 6$ \\
\hline Origin of dorsal fin base - origin of ventral fin base & $1 \times 7$ \\
\hline Origin of dorsal fin base - origin of pectoral fin base & $1 \times 9$ \\
\hline Origin of dorsal fin base - posterior aspect of operculum & $1 \times 11$ \\
\hline Insertion of dorsal fin base - origin of above caudal fin base & $2 \times 3$ \\
\hline Insertion of dorsal fin base - origin of bottom caudal fin base & $2 \times 4$ \\
\hline Insertion of dorsal fin base - insertion of anal fin base & $2 \times 5$ \\
\hline Origin of above caudal fin base - origin of bottom caudal fin base & $3 \times 4$ \\
\hline Origin of above caudal fin base - insertion of anal fin base & $3 \times 5$ \\
\hline Origin of above caudal fin base - origin of anal fin base & $3 \times 6$ \\
\hline Origin of bottom caudal fin base - insertion of anal fin base & $4 \times 5$ \\
\hline Insertion of anal fin base - origin of anal fin base & $5 \times 6$ \\
\hline Origin of anal fin base - origin of ventral fin base & $6 \times 7$ \\
\hline Origin of anal fin base - origin of pectoral fin base & $6 \times 9$ \\
\hline Origin of anal fin base - posterior aspect of operculum & $6 \times 11$ \\
\hline Origin of ventral fin base - posterior aspect of operculum & $7 \times 8$ \\
\hline Origin of ventral fin base - origin of pectoral fin base & $7 \times 9$ \\
\hline Origin of ventral fin base - posterior aspect of operculum & $7 \times 11$ \\
\hline Origin of pectoral fin base - insertion of pectoral fin base & $9 \times 10$ \\
\hline Origin of pectoral fin base - posterior aspect of operculum & $9 \times 11$ \\
\hline \multicolumn{2}{|l|}{ Head part dimension } \\
\hline Head length $(H L)$ & $1 \times 4$ \\
\hline Most anterior extension of the head - above of nostril & $1 \times 2$ \\
\hline Most anterior extension of the head - above of eye & $1 \times 3$ \\
\hline Most anterior extension of the head - snout & $1 \times 5$ \\
\hline Above of nostril - above of eye & $2 \times 3$ \\
\hline Above of nostril - posterior aspect of operculum & $2 \times 4$ \\
\hline Above of nostril - snout & $2 \times 5$ \\
\hline Above of eye - posterior aspect of operculum & $3 \times 4$ \\
\hline Above of eye - snout & $3 \times 5$ \\
\hline Posterior aspect of operculum - snout & $4 \times 5$ \\
\hline \multicolumn{2}{|l|}{ Eye diameter } \\
\hline Interorbital width & \\
\hline
\end{tabular}




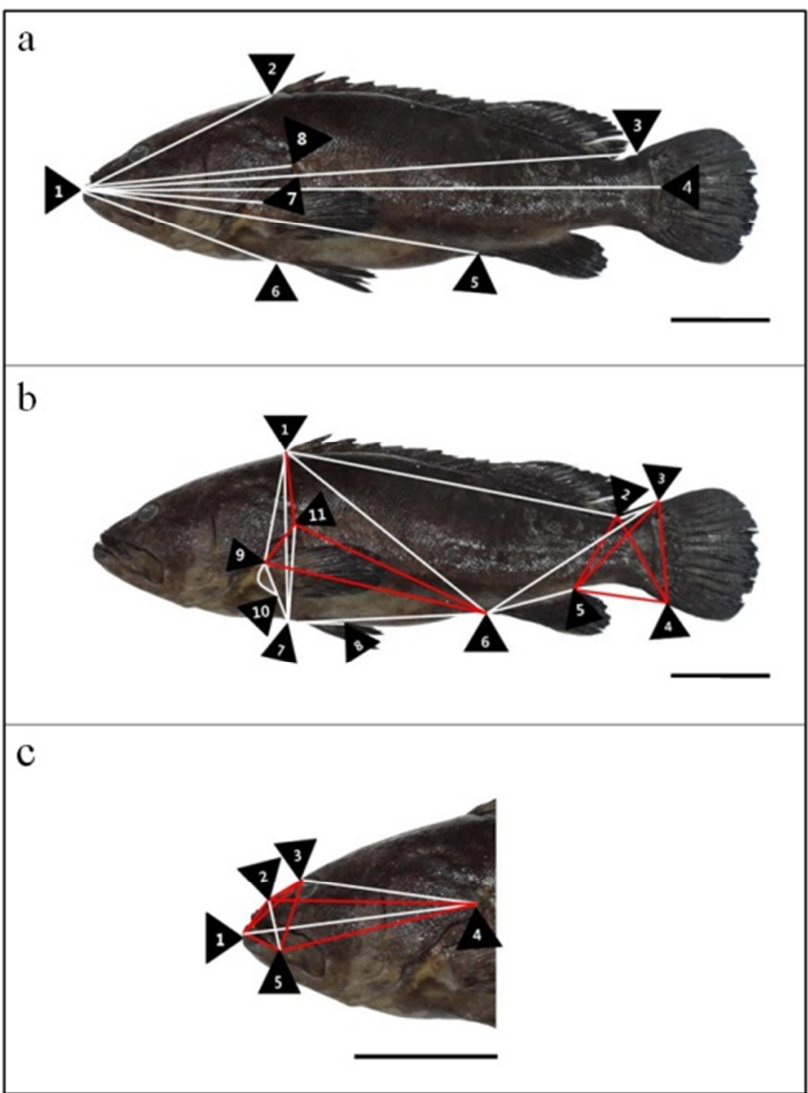

Fig. 1. Morphometric measurements of classical dimension (a), truss dimension (b) and head part dimension (c) in kelp grouper, Epinephelus bruneus. Red lines: kelp grouper has greater distances more than the other Serranidae; White lines: 3 fishes were not found significantly correlated distances. Scale bars indicate $6 \mathrm{~cm}$. Details of the measured distances of morphometric characteristics are described in Table 1.

To compare the meristic variations of counts for each species, in total, 8 fin rays dorsal fin spine $\left(D_{F} R_{1}\right)$, anal fin spine $\left(\mathrm{AFR}_{1}\right)$ and ventral fin spine $\left(\mathrm{VFR}_{1}\right)$ and soft rays composed of dorsal soft ray $\left(\mathrm{DFR}_{2}\right)$, anal soft ray $\left(\mathrm{AFR}_{2}\right)$, caudal soft ray $\left(\mathrm{CFR}_{2}\right)$, pectoral soft ray $\left(\mathrm{PFR}_{2}\right)$, and ventral soft ray $\left(\mathrm{VFR}_{2}\right)$ were counted, respectively.

\section{X-ray photograph}

For visualize the vertebrae, skeleton and swim bladder of whole fish by radiographic x-ray photographs (Bailey \& Gosline, 1955; Chang \& Magnuson, 1968), images were taken of the lateral view of overall body shape of 10 defrosted samples of each species, respectively, and images were made on a x-ray machine (Fire CR, 3 Disc Imaging, Korea).

As shown in Fig. 4, we described dotted line between straight line and highest one in abdominal vertebrae to measure the curvature degree of the vertebrae column. Measuring the extent of swim bladder was performed through the big dotted line and small dotted line, big dotted line displayed maximum width of swim bladder and small dotted line showed maximum height of swim bladder. The measured results of dotted line and arrow divided into distance of standard length $1 \times 4(S L)$.

\section{Statistical analysis}

The study was performed in triplicate, and the results are reported as means $\pm \mathrm{SD}(n=150)$, unless otherwise stated. The data were analyzed with one-way analysis of variance (ANOVA) using the SPSS statistical package (SPSS 9.0, SPSS Inc., Chicago, IL, USA). The means were compared with Duncan's multiple range test, and were considered significantly different at $P<0.05$.

\section{RESULTS}

\section{Landmark-based morphometric traits}

Body coloration of kelp grouper (Epinephelus bruneus) composed of typically purplish brown color and designed 6 dark brown pattern but pattern shape were not constant, red spotted grouper (E. akaara) had generally reddishbrown color often with many white spots, and seven-banded grouper (E. septemfasciatus) had grayish brown body color and composed of 7 dark brown pattern. As age increased, kelp grouper and seven banded grouper fainted off the pattern of bands, eventually disappeared (Figs. 1, 2 and 3).

Multivariate morphometric analysis was performed on external body shape, 38 various morphometric distances and 24 coefficients of Serranidae are given in Table 1, and 
Table 2. Classical dimension results of kelp grouper (Epinephelus bruneus), red spotted grouper (E. akaara) and seven-banded grouper (E. septemfasciatus) ${ }^{*}$

\begin{tabular}{cccc}
\hline \hline $\begin{array}{c}\text { Morphometric } \\
\text { measurements }\end{array}$ & $\begin{array}{c}\text { E. bruneus } \\
(\%)\end{array}$ & $\begin{array}{c}\text { E. akaara } \\
(\%)\end{array}$ & $\begin{array}{c}\text { E. } \\
\text { septemfasciatus } \\
(\%)\end{array}$ \\
\hline $1 \times 2 / S L$ & $38.5 \pm 2.14^{\mathrm{a}}$ & $41.0 \pm 2.44^{\mathrm{a}}$ & $40.9 \pm 1.98^{\mathrm{a}}$ \\
$1 \times 3 / S L$ & $99.8 \pm 2.46^{\mathrm{a}}$ & $99.1 \pm 2.65^{\mathrm{a}}$ & $97.8 \pm 3.66^{\mathrm{a}}$ \\
$1 \times 5 / S L$ & $70.8 \pm 1.96^{\mathrm{a}}$ & $68.9 \pm 4.83^{\mathrm{a}}$ & $69.6 \pm 3.65^{\mathrm{a}}$ \\
$1 \times 6 / S L$ & $38.8 \pm 2.58^{\mathrm{a}}$ & $39.7 \pm 2.15^{\mathrm{a}}$ & $39.3 \pm 2.84^{\mathrm{a}}$ \\
$1 \times 7 / S L$ & $35.6 \pm 2.47^{\mathrm{a}}$ & $36.2 \pm 0.98^{\mathrm{a}}$ & $36.4 \pm 2.39^{\mathrm{a}}$ \\
$1 \times 8 / S L$ & $31.5 \pm 2.12^{\mathrm{a}}$ & $39.7 \pm 2.14^{\mathrm{b}}$ & $33.2 \pm 2.48^{\mathrm{a}}$ \\
\hline
\end{tabular}

${ }^{*}$ For abbreviations and each dimension, see Table 1 and Figs. 1a, 2a and 3a. The values are means $\pm \operatorname{SD}(n=150)$ of triplicate groups. Data were analyzed using one-way ANOVA on data transformed to the arcsine of the square root. Different capital letters on the values indicate statistical significance among morphometric distances $(P<0.05)$. Different small letters on the values indicate statistical significance among ratios of morphometric dimension/ standard length $(S L)(P<0.05)$. Different small letters on 'a' means the smallest value, ' $b$ ' means larger than ' $a$ ' value and ' $c$ ' means the largest value among 3 species data.

Figs. 1, 2 and 3. Comparison distances of classical dimensions (CD) were landmark pointed fin rays and operculum (Figs. 1a, 2a and 3a), distances transversally divided into 6 morphometric measurements (Table 2). Also, CD dimensions and TD dimensions were divided into distance of standard length $1 \times \mathbf{4}(S L)$. Table 2 shows morphometric formula (dimensions/SL), all measurements were not found significantly correlated $(P>0.05)$. Results of CD cluster analysis showed that 3 fishes were undiscovered differences (Table 2 and Figs 1a, 2a and 3a.).

The truss dimension described external fish body and various point digitized (Figs. $1 b, 2 b$ and $3 b$ ), distances divided into 21 morphometric measurements (Table 3). As shown in Table 3 morphometric formula (dimensions/SL), comparison of fin ray distance; kelp grouper has the greatest value in $\mathbf{3} \times \mathbf{4}$ and seven-banded grouper has the greatest value in $\mathbf{5} \times \mathbf{6}(P<0.05)$. The remaining measurements,

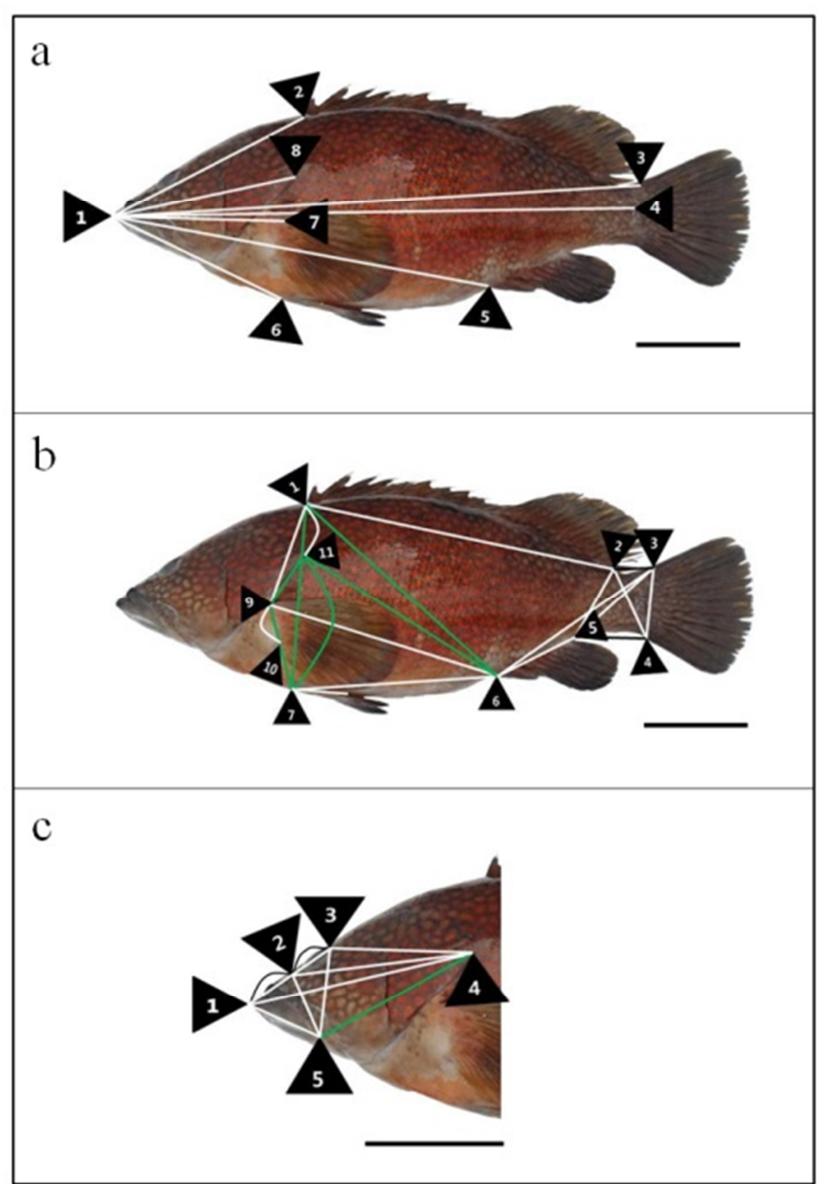

Fig. 2. Morphometric measurements of classical dimension (a), truss dimension (b) and head part dimension (c) in red spotted grouper, E. akaara. Green lines: red spotted grouper has greater distances more than the other Serranidae; White lines: 3 fishes were not found significantly correlated distances. Scale bars indicate $6 \mathrm{~cm}$. Details of the measured distances of morphometric characteristics are described in Table 1.

$\mathbf{1} \times \mathbf{2}, 7 \times \mathbf{8}$ and $\mathbf{9} \times \mathbf{1 0}$ were not significantly correlated $(P>$ $0.05)$. On the basis of origin of dorsal fin base (ODFB), kelp grouper has smaller values than the others in $\mathbf{1} \times \mathbf{6}$ and $1 \times 7$, seven-banded grouper has the greatest value in $1 \times 9$ and red spotted grouper has smallest values in $\mathbf{1} \times \mathbf{1 1}(P<$ $0.05)$.

On the basis of insertion of dorsal fin base (IDFB), seven-banded grouper has the greatest value in $2 \times 3$ and kelp grouper has greatest values in $\mathbf{2} \times \mathbf{4}$ and $\mathbf{2} \times \mathbf{5}(P<0.05)$. On the basis of origin of above caudal fin base 
Table 3. Truss dimension results of kelp grouper (Epinephelus bruneus), red spotted grouper (E. akaara) and seven-banded grouper (E. septemfasciatus) ${ }^{*}$

\begin{tabular}{|c|c|c|c|}
\hline $\begin{array}{l}\text { Morphometric } \\
\text { measurements }\end{array}$ & $\begin{array}{c}\text { E. bruneus } \\
(\%)\end{array}$ & $\begin{array}{c}\text { E. akaara } \\
(\%)\end{array}$ & $\begin{array}{c}\text { E. } \\
\text { septemfasciatu } \\
(\%)\end{array}$ \\
\hline $1 \times 2 / S L$ & $54.0 \pm 2.54^{\mathrm{a}}$ & $55.5 \pm 3.11^{\mathrm{a}}$ & $55.3 \pm 2.91^{\mathrm{a}}$ \\
\hline $1 \times 6 / S L$ & $44.7 \pm 1.64^{\mathrm{a}}$ & $48.3 \pm 3.64^{b}$ & $47.7 \pm 2.13^{b}$ \\
\hline $1 \times 7 / S L$ & $28.9 \pm 1.31^{\mathrm{a}}$ & $34.6 \pm 1.62^{b}$ & $33.8 \pm 1.86^{\mathrm{b}}$ \\
\hline $1 \times 9 / S L$ & $21.6 \pm 1.02^{\mathrm{a}}$ & $22.1 \pm 1.37^{\mathrm{a}}$ & $24.6 \pm 1.25^{\mathrm{b}}$ \\
\hline $1 \times 11 / S L$ & $12.8 \pm 1.89^{\mathrm{b}}$ & $9.7 \pm 1.84^{\mathrm{a}}$ & $13.6 \pm 1.60^{\mathrm{b}}$ \\
\hline $2 \times 3 / S L$ & $9.6 \pm 1.70^{\mathrm{a}}$ & $9.2 \pm 1.90^{\mathrm{a}}$ & $12.5 \pm 1.03^{b}$ \\
\hline $2 \times 4 / S L$ & $17.5 \pm 1.62^{b}$ & $14.3 \pm 1.67^{\mathrm{a}}$ & $14.0 \pm 2.47^{\mathrm{a}}$ \\
\hline $2 \times 5 / S L$ & $16.1 \pm 1.46^{\mathrm{b}}$ & $12.0 \pm 1.39^{\mathrm{a}}$ & $11.4 \pm 2.24^{\mathrm{a}}$ \\
\hline $3 \times 4 / S L$ & $15.9 \pm 1.35^{\mathrm{b}}$ & $12.9 \pm 1.14^{\mathrm{a}}$ & $11.9 \pm 1.38^{\mathrm{a}}$ \\
\hline $3 \times 5 / S L$ & $18.8 \pm 0.92^{\mathrm{b}}$ & $14.5 \pm 2.03^{\mathrm{a}}$ & $14.6 \pm 2.84^{\mathrm{a}}$ \\
\hline $3 \times 6 / S L$ & $35.1 \pm 2.10^{\mathrm{a}}$ & $36.5 \pm 1.13^{\mathrm{a}}$ & $36.7 \pm 2.89^{\mathrm{a}}$ \\
\hline $4 \times 5 / S L$ & $18.1 \pm 1.53^{\mathrm{b}}$ & $14.9 \pm 1.76^{\mathrm{a}}$ & $14.4 \pm 1.41^{\mathrm{a}}$ \\
\hline $5 \times 6 / S L$ & $16.8 \pm 1.14^{\mathrm{a}}$ & $16.1 \pm 1.10^{\mathrm{a}}$ & $20.8 \pm 1.15^{\mathrm{b}}$ \\
\hline $6 \times 7 / S L$ & $30.2 \pm 2.72^{\mathrm{a}}$ & $30.3 \pm 1.88^{\mathrm{a}}$ & $31.3 \pm 2.93^{\mathrm{a}}$ \\
\hline $6 \times 9 / S L$ & $37.3 \pm 2.37^{b}$ & $36.4 \pm 2.66^{\mathrm{b}}$ & $33.5 \pm 1.75^{\mathrm{a}}$ \\
\hline $6 \times 11 / S L$ & $37.6 \pm 2.17^{\mathrm{b}}$ & $38.6 \pm 2.23^{b}$ & $34.2 \pm 1.58^{\mathrm{a}}$ \\
\hline $7 \times 8 / S L$ & $9.2 \pm 1.40^{\mathrm{a}}$ & $9.5 \pm 1.89^{\mathrm{a}}$ & $10.7 \pm 1.39^{\mathrm{a}}$ \\
\hline $7 \times 9 / S L$ & $10.5 \pm 1.37^{\mathrm{a}}$ & $14.1 \pm 1.14^{\mathrm{b}}$ & $11.6 \pm 1.26^{\mathrm{a}}$ \\
\hline $7 \times 11 / S L$ & $19.5 \pm 1.58^{b}$ & $23.8 \pm 1.71^{\mathrm{c}}$ & $15.7 \pm 1.80^{\mathrm{a}}$ \\
\hline $9 \times 10 / S L$ & $6.3 \pm 0.68^{\mathrm{a}}$ & $6.6 \pm 1.55^{\mathrm{a}}$ & $6.4 \pm 0.53^{\mathrm{a}}$ \\
\hline $9 \times 11 / S L$ & $11.9 \pm 1.08^{\mathrm{b}}$ & $12.7 \pm 1.29^{b}$ & $6.8 \pm 1.50^{\mathrm{a}}$ \\
\hline
\end{tabular}

*For abbreviations and each dimension, see Table 1 and Figs. $1 \mathrm{~b}, 2 \mathrm{~b}$ and $3 \mathrm{~b}$. The values are means $\pm \mathrm{SD}(n=150)$ of triplicate groups. Data were analyzed using one-way ANOVA on data transformed to the arcsine of the square root. Different capital letters on the values indicate statistical significance among morphometric distances $(P$ $<0.05)$. Different small letters on the values indicate statistical significance among ratios of morphometric dimension/standard length $(S L)(P<0.05)$. Different small letters on ' $a$ ' means the smallest value, ' $b$ ' means larger than ' $a$ ' value and ' $c$ ' means the largest value among 3 species data.
(OACFB), kelp grouper has greatest values in $\mathbf{3} \times \mathbf{5}(P<$ $0.05)$ and $\mathbf{3} \times \mathbf{6}$ was not significantly correlated in group $(P$ $>0.05)$. On the basis of origin of bottom caudal fin base (OBCFB), kelp grouper has greatest values in $\mathbf{4} \times \mathbf{5}(P<$ $0.05)$. On the basis of origin of anal fin base (OAFB), red spotted grouper has the smallest values in $6 \times 9$ and $6 \times 11$, and $6 \times 7$ have not significantly correlated in group $(P>$

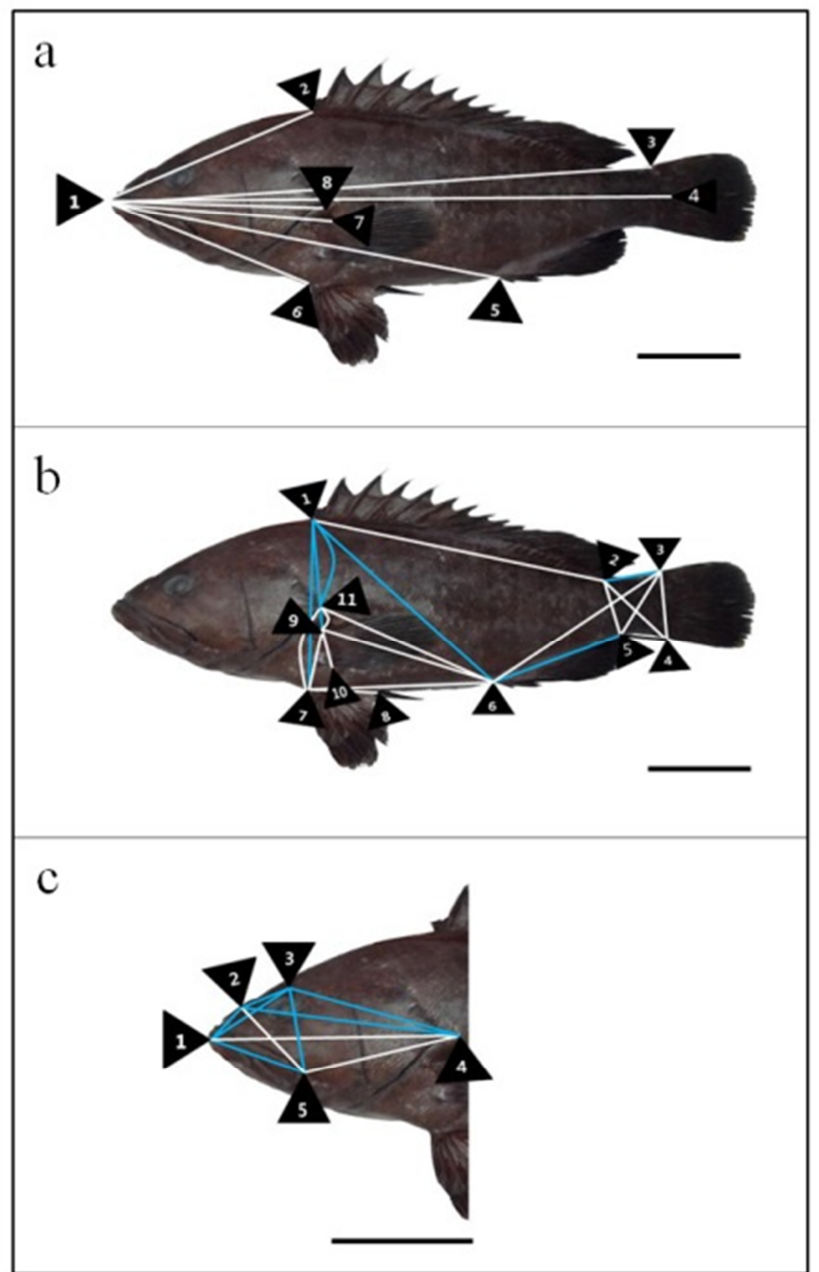

Fig. 3. Morphometric measurements of classical dimension (a), truss dimension (b) and head part dimension (c) in seven-banded grouper, $E$. septemfasciatus. Blue lines: seven-banded grouper has greater distances more than the other Serranidae; White lines: 3 fishes were not found significantly correlated distances. Scale bars indicate $6 \mathrm{~cm}$. Details of the measured distances of morphometric characteristics are described in Table 1. 
0.05). On the basis of origin of ventral fin base (OVFB), red spotted grouper has greatest values in 7X9 and seven banded grouper has the smallest values in 7X11 $(P<0.05)$.

Origin of pectoral fin base (OPFB) to posterior aspect of operculum (PAO): 9X11, seven banded grouper has the smallest value in group $(P<0.05)$. Results of TD cluster analysis showed that kelp grouper has 4 dimension greater values, red spotted grouper has 7 dimension greater values

Table 4. Head part dimension results of kelp grouper (Epinephelus bruneus), red spotted grouper (E. akaara) and seven-banded grouper $(E$. septemfasciatus)*

\begin{tabular}{cccc}
\hline \hline $\begin{array}{c}\text { Morphometric } \\
\text { measurements }\end{array}$ & $\begin{array}{c}\text { E. bruneus } \\
(\%)\end{array}$ & $\begin{array}{c}\text { E. akaara } \\
(\%)\end{array}$ & $\begin{array}{c}\text { E. } \\
\text { septemfasciatus } \\
(\%)\end{array}$ \\
\hline $1 \times 2 / H L$ & $28.3 \pm 4.27^{\mathrm{b}}$ & $23.6 \pm 2.60^{\mathrm{a}}$ & $26.9 \pm 3.16^{\mathrm{b}}$ \\
$1 \times 3 / H L$ & $38.2 \pm 2.52^{\mathrm{b}}$ & $33.7 \pm 3.23^{\mathrm{a}}$ & $42.5 \pm 3.26^{\mathrm{c}}$ \\
$1 \times 5 / H L$ & $40.8 \pm 1.92^{\mathrm{c}}$ & $34.1 \pm 2.64^{\mathrm{a}}$ & $37.0 \pm 2.77^{\mathrm{b}}$ \\
$2 \times 3 / H L$ & $17.7 \pm 3.54^{\mathrm{b}}$ & $12.5 \pm 2.03^{\mathrm{a}}$ & $16.9 \pm 2.79^{\mathrm{b}}$ \\
$2 \times 4 / H L$ & $78.3 \pm 2.82^{\mathrm{b}}$ & $74.4 \pm 3.27^{\mathrm{a}}$ & $79.5 \pm 2.58^{\mathrm{b}}$ \\
$2 \times 5 / H L$ & $26.4 \pm 3.17^{\mathrm{a}}$ & $27.6 \pm 3.02^{\mathrm{a}}$ & $27.4 \pm 2.91^{\mathrm{a}}$ \\
$3 \times 4 / H L$ & $66.7 \pm 2.58^{\mathrm{a}}$ & $67.6 \pm 1.52^{\mathrm{a}}$ & $70.1 \pm 2.78^{\mathrm{b}}$ \\
$3 \times 5 / H L$ & $37.8 \pm 2.19^{\mathrm{b}}$ & $31.7 \pm 3.41^{\mathrm{a}}$ & $38.2 \pm 3.50^{\mathrm{b}}$ \\
$4 \times 5 / H L$ & $82.3 \pm 2.93^{\mathrm{b}}$ & $80.2 \pm 4.42^{\mathrm{b}}$ & $75.3 \pm 2.49^{\mathrm{a}}$ \\
\hline Eye diameter & $1.45 \pm 0.14^{\mathrm{a}}$ & $1.58 \pm 0.34^{\mathrm{a}}$ & $1.42 \pm 0.21^{\mathrm{a}}$ \\
\hline Interorbital & $2.41 \pm 0.31^{\mathrm{b}}$ & $1.98 \pm 0.21^{\mathrm{a}}$ & $2.36 \pm 0.25^{\mathrm{b}}$ \\
width & & & \\
\hline
\end{tabular}

${ }^{*}$ For abbreviations and each dimension, see Table 1 and Figs. $1 \mathrm{c}, 2 \mathrm{c}$ and $3 \mathrm{c}$. The values are means $\pm \mathrm{SD}(n=150)$ of triplicate groups. Data were analyzed using one-way ANOVA on data transformed to the arcsine of the square root. Different capital letters on the values indicate statistical significance among morphometric distances $(P<0.05)$. Different small letters on the values indicate statistical significance among ratios of morphometric dimension/ standard length $(S L)(P<0.05)$. Different small letters on ' $a$ ' means the smallest value, ' $b$ ' means larger than ' $a$ ' value and ' $c$ ' means the largest value among 3 species data. and seven-banded grouper has 11 dimension greater values in TD (Table 2, and Figs. 1b, 2b and 3b).

Head part dimension is intensively described the head of fish (Figs. 1c, 2c and 3c), distances divided into 11 morphometric measurements (Table 4). Table 4 shows morphometric formula (dimensions $/ H L$ ), on the basis of most anterior extension of the head (MAEH), red spotted grouper
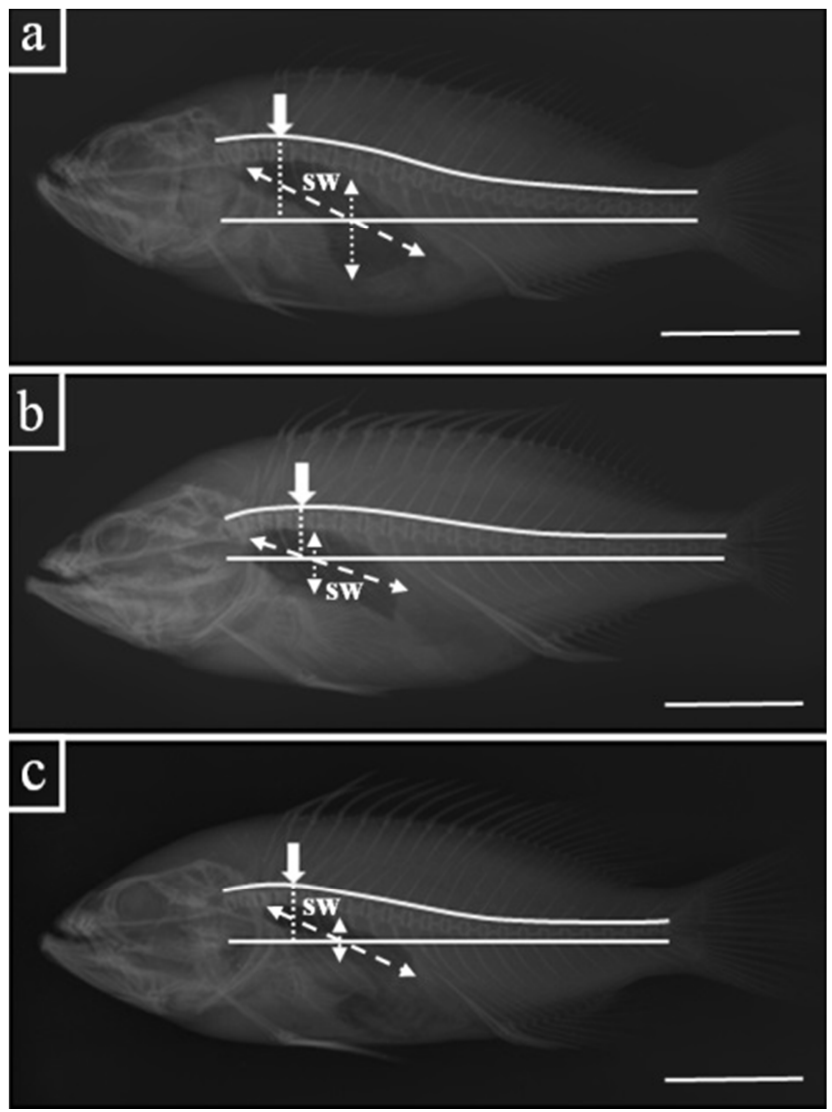

Fig. 4. X-ray image of skeleton in kelp grouper (Epinephelus bruneus) (a), red spotted grouper (E. akaara) (b) and seven-banded grouper (E. septemfasciatus) (c). SW: swim bladder; Big dotted arrow: maximum width; Small dotted arrow: maximum height; Arrow point: highest one in abdominal vertebrae; Dotted line: the distance between straight line and highest one in abdominal vertebrae. Note: Euphemistic line means curved shape of vertebrae column and straight line means distance at the start and end of the vertebral column. Scale bars indicate $6 \mathrm{~cm}$. 
Table 5. Meristic characteristics of kelp grouper (Epinephelus bruneus), red spotted grouper (E. akaara) and sevenbanded grouper (E. septemfasciatus) ${ }^{*}$

\begin{tabular}{ccccc}
\hline \hline $\begin{array}{c}\text { Meristic } \\
\text { characterictics }\end{array}$ & & E. bruneus & E. akaara & E. septemfasciatus \\
\hline Fin rays & & & & \\
\hline \multirow{2}{*}{ Dorsal } & Spinous rays & $10.5 \pm 0.66^{\mathrm{a}}(\mathrm{IX} \sim \mathrm{XII})$ & $10.3 \pm 0.17^{\mathrm{a}}(\mathrm{X} \sim \mathrm{XI})$ & $11.2 \pm 0.53^{\mathrm{a}}(\mathrm{X} \sim \mathrm{XII})$ \\
& Soft rays & $13.5 \pm 0.21^{\mathrm{a}}(13 \sim 14)$ & $15.4 \pm 0.37^{\mathrm{b}}(15 \sim 16)$ & $14.8 \pm 0.54^{\mathrm{b}}(14 \sim 16)$ \\
\hline \multirow{2}{*}{ Anal } & Spinous rays & $3.4 \pm 0.19^{\mathrm{b}}(\mathrm{III} \sim \mathrm{IV})$ & $2.7 \pm 0.17^{\mathrm{a}}(\mathrm{II} \sim \mathrm{III})$ & $2.4 \pm 0.12^{\mathrm{a}}(\mathrm{II} \sim \mathrm{III})$ \\
& Soft rays & $9.3 \pm 0.27^{\mathrm{b}}(9 \sim 10)$ & $7.1 \pm 0.36^{\mathrm{a}}(6 \sim 7)$ & $9.5 \pm 0.35^{\mathrm{b}}(9 \sim 10)$ \\
\hline Caudal & Soft rays & $16.7 \pm 0.18^{\mathrm{b}}(16 \sim 17)$ & $15.2 \pm 0.51^{\mathrm{a}}(14 \sim 15)$ & $17.2 \pm 0.34^{\mathrm{b}}(16 \sim 18)$ \\
\hline Pectoral & Soft rays & $16.5 \pm 0.27^{\mathrm{a}}(16 \sim 17)$ & $17.3 \pm 0.43^{\mathrm{a}}(16 \sim 18)$ & $17.2 \pm 0.29^{\mathrm{a}}(16 \sim 18)$ \\
\hline \multirow{2}{*}{ Ventral } & Spinous rays & $1.6 \pm 0.27^{\mathrm{a}}(\mathrm{I} \sim \mathrm{II})$ & $1.3 \pm 0.13^{\mathrm{a}}(\mathrm{I} \sim \mathrm{II})$ & $2.4 \pm 0.12^{\mathrm{a}}(\mathrm{I} \sim \mathrm{II})$ \\
& Soft rays & $4.4 \pm 0.31^{\mathrm{a}}(4 \sim 5)$ & $5.3 \pm 0.41^{\mathrm{a}}(4 \sim 5)$ & $4.9 \pm 0.46^{\mathrm{a}}(4 \sim 5)$ \\
\hline Vertebrae & & $24.7 \pm 0.27^{\mathrm{a}}(24 \sim 25)$ & $24.3 \pm 0.11^{\mathrm{a}}(24 \sim 25)$ & $24.5 \pm 0.35^{\mathrm{a}}(24 \sim 25)$ \\
\hline
\end{tabular}

* The values are means \pm SD $(n=150)$ of triplicate groups. Data were analyzed using one-way ANOVA on data transformed to the arcsine of the square root. Different capital letters on the values indicate statistical significance among meristic characteristics $(P<0.05)$. Refer to the Figs. 1, 2 and 3. Different small letters on 'a' means the smallest value, 'b' means larger than ' $a$ ' value and ' $c$ ' means the largest value among 3 species data.

has the smallest values in $\mathbf{1} \times \mathbf{2}, \mathbf{1} \times \mathbf{3}$ and $\mathbf{1} \times \mathbf{5}(P<0.05)$. On the basis of above of nostril (AN), red spotted grouper has the smallest values in $\mathbf{2} \times \mathbf{3}$ and $\mathbf{2} \times \mathbf{4}$. On the basis of above of eye (AE), $\mathbf{3} \times \mathbf{4}$ and $\mathbf{3} \times \mathbf{5}$ have not found significantly correlated in group $(P>0.05)$. Posterior aspect of operculum (PAO) to posterior aspect of snout (PAS): $\mathbf{4} \times \mathbf{5}$, sevenbanded grouper has the smallest value in group $(P<0.05)$.

Followed by, eye diameter (ED) has not found significantly correlated in group $(P>0.05)$ and interorbital width (IW), red spotted grouper has the smallest value in group $(P<$ 0.05). Results of HD cluster analysis showed that kelp grouper has 7 dimensions greater values, red spotted grouper has 1 dimension greater value and seven-banded grouper has 7 dimensions greater values in HD (Table 2 and Figs. $1 \mathrm{c}, 2 \mathrm{c}$ and $3 \mathrm{c})$.

\section{Meristic characteristics}

As shown in Table 5, the meristic counts of $\mathrm{DFR}_{1}, \mathrm{PFR}_{1}$, $\mathrm{VFR}_{1}$ and $\mathrm{VFR}_{2}$ were not found significant differences in individual each fin ray $\left(\mathrm{DFR}_{1}\right.$, kelp grouper $=10.5 \pm 0.66^{\mathrm{a}}$, red spotted grouper $=10.3 \pm 0.17^{\mathrm{a}}$, seven-banded grouper= $11.2 \pm 0.53^{\mathrm{a}} ; \mathrm{PFR}_{1}$, kelp grouper $=16.5 \pm 0.27^{\mathrm{a}}$, red spotted grouper $=17.3 \pm 0.43^{\mathrm{a}}$, seven-banded grouper $=17.2 \pm 0.34^{\mathrm{b}}$; $\mathrm{VFR}_{1}$, kelp grouper $=1.6 \pm 0.27^{\mathrm{a}}$, red spotted grouper= $1.3 \pm 0.13^{\mathrm{a}}$, seven-banded grouper $=2.4 \pm 0.12^{\mathrm{a}} ; \mathrm{VFR}_{2}$, kelp grouper $=4.4 \pm 0.31^{\mathrm{a}}$, red spotted grouper $=5.3 \pm 0.41^{\mathrm{a}}$, sevenbanded grouper $\left.=4.9 \pm 0.46^{\mathrm{a}}\right)(P>0.05)$.

Significant differences of fin rays found in $\mathrm{DFR}_{2}, \mathrm{AFR}_{1}$, $\mathrm{AFR}_{2}$ and $\mathrm{CFR}_{2}\left(\mathrm{DFR}_{2}\right.$, kelp grouper $=13.5 \pm 0.21^{\mathrm{a}}$, red spotted grouper $=15.4 \pm 0.37^{\mathrm{b}}$, seven-banded grouper $=14.8 \pm 0.54^{\mathrm{b}}$; $\mathrm{AFR}_{1}$, kelp grouper $=3.4 \pm 0.19^{\mathrm{b}}$, red spotted grouper= $2.7 \pm 0.17^{\mathrm{a}}$, seven-banded grouper $=2.4 \pm 0.12^{\mathrm{a}} ; \mathrm{AFR}_{2}$, kelp grouper $=9.3 \pm 0.27^{\mathrm{b}}$, red spotted grouper $=7.1 \pm 0.36^{\mathrm{a}}$, sevenbanded grouper $=9.5 \pm 0.35^{\mathrm{b}} ; \mathrm{CFR}_{2}$, kelp grouper $=16.7 \pm 0.18^{\mathrm{b}}$, red spotted grouper $=15.2 \pm 0.51^{\mathrm{a}}$, seven-banded grouper= $\left.17.2 \pm 0.34^{\mathrm{b}}\right)(P<0.05)$.

Results of different meristic characteristics were showed that kelp grouper had more $\mathrm{AFR}_{1}, \mathrm{AFR}_{2}$, red spotted grouper had more $\mathrm{DFR}_{2}$, and seven banded grouper had more $\mathrm{DFR}_{2}, \mathrm{AFR}_{2}$ and $\mathrm{CFR}_{2}$. 
Table 6. Measurements of x-ray photographed swim bladder and curved vertebral column of (Epinephelus bruneus), red spotted grouper (E. akaara) and seven-banded grouper (E. septemfasciatus)*

\begin{tabular}{ccccc}
\hline \hline X-ray parts & Measurements & E. bruneus & E. akaara & E. septemfasciatus \\
\hline \multirow{3}{*}{ Swim bladder } & Extent $\left(\mathrm{cm}^{2}\right)$ & $25.2 \pm 1.78^{\mathrm{c}}$ & $17.7 \pm 1.41^{\mathrm{b}}$ & $13.2 \pm 2.15^{\mathrm{a}}$ \\
& Maximum height $/ S L(\%)$ & $10.7 \pm 0.85^{\mathrm{b}}$ & $7.3 \pm 0.93^{\mathrm{a}}$ & $6.6 \pm 1.19^{\mathrm{a}}$ \\
& Maximum width $/ S L(\%)$ & $15.6 \pm 1.25^{\mathrm{a}}$ & $15.2 \pm 1.31^{\mathrm{a}}$ & $15.5 \pm 1.28^{\mathrm{a}}$ \\
\hline Vertebral column & Dotted line $/ S L(\%)$ & $8.2 \pm 0.81^{\mathrm{b}}$ & $5.5 \pm 1.17^{\mathrm{a}}$ & $5.2 \pm 0.94^{\mathrm{a}}$ \\
\hline
\end{tabular}

* The values are means $\pm \mathrm{SD}(n=30)$ of triplicate groups. Data were analyzed using one-way ANOVA on data transformed to the arcsine of the square root. Different capital letters on the values indicate statistical significance among meristic characteristics $(P<0.05)$. Refer to the Figs. 4. Different small letters on 'a' means the smallest value, 'b' means larger than 'a' value and 'c' means the largest value among 3 species data.

\section{X-ray photograph}

Comparison of swim bladder extent was showed that kelp grouper was $25.2 \pm 1.78^{\mathrm{c}}$, red spotted grouper was $17.7 \pm 1.41^{\mathrm{b}}$, and seven banded grouper was $13.2 \pm 2.15^{\mathrm{a}}(P$ $<0.05$ ). Measured results of maximum height and width, and dotted line were divided into distance of standard length $1 \times 4(S L)$.

Maximum height was measured that kelp grouper was $10.7 \pm 0.85^{\mathrm{b}}$, red spotted grouper was $7.3 \pm 0.93^{\mathrm{a}}$, and seven banded grouper was $6.6 \pm 1.19^{\mathrm{a}}(P<0.05)$. Followed by, maximum width was measured that kelp grouper was $15.6 \pm 1.25^{\mathrm{a}}$, red spotted grouper was $15.2 \pm 1.31^{\mathrm{a}}$, and seven banded grouper was $15.5 \pm 1.28^{\mathrm{a}}(P<0.05)$.

Dotted line distances of vertebral column was displayed that kelp grouper was $8.2 \pm 0.81^{\mathrm{b}}$, red spotted grouper was $5.5 \pm 1.17^{\mathrm{a}}$, and seven banded grouper was $5.2 \pm 0.94^{\mathrm{a}}(P<$ $0.05)$. Vertebrae counts were not found significantly correlated; all samples have 24 25 vertebrae, respectively $(P>0.05)$.

Unlike the external form, X-ray photograph detailedly showed skull, maxilla, mandibula, supraorbital and etc. Red spotted grouper has the sharpest skull and kelp grouper has the biggest supraorbital, thus red spotted grouper and seven-banded grouper has similar skeleton structure.

\section{DISCUSSION}

Genetically determined the morphometric analysis and meristic characteristics were evidence to identify the stock identification (Ihssen et al., 1981; Park et al., 2003). However, various situation made different body shape, high plasticity and mutated organ (Barlow, 1961; Lindsey, 1988). Morphological variation was classified by the modified and changed body structure which composed of linear and landmark-based morphometric methods and counting of meristic variations (Bookstein, 1991; Melvin et al., 1992; Hurlbut \& Clay, 1998; Nakamura, 2003; Turan et al., 2006). Morphological analysis is analogize the starvation and satiety situation, and determine the nutritive conditions. Truss dimension is anatomically divided into body shape (Straüss \& Bookstein, 1982; Bookstein, 1991) and considered as useful tools with more complicated and sophisticated descriptions of external structure and body shape. The truss dimensions are the primary units of classification for the identifying the modification of body shape (Straüss \& Bond, 1990).

Results of classical dimension shows horizontal distances, 3 fishes were not significantly correlated $(P>0.05)$, it means epinephelus fishes had long standard length (Fukuhara, 1989) and truss dimension shows anatomically distances, and randomly measured, rearward of kelp grouper (Epinephelus bruneus), have larger than other fishes, red spotted grouper (E. akaara) and seven-banded grouper (E. septemfasciatus) have larger body width and body depth than kelp grouper. 
These 3 species have a same fusiform appearance, but different external environment and feeding habits attributed to make a dissimilarly morphometric body shape (Saima \& Onkar, 2015). Head part dimension distinctly represented differences in 3 samples, red spotted grouper had different maxillary and mandible because of the sharpest skull, therefore dissimilar head size derived from different feeding habit and inhabitation (Fukuhara, 1989; Nakamura, 2003; Saima \& Onkar, 2015).

Meristic variables are demonstrated the stock identification and considered as taxonomic status (Ihssen et al., 1981). Number of fin rays contributed to the velocity of water flow and it possible operate the sensory organ that detects water flow, water pressure and vibration, and the more developed the lateral line, the more advantageous it becomes for the detection of prey (Videler, 1993). Dorsal fin ray and caudal fin ray accelerate swimming velocity, and anal fin ray and pectoral fin ray adjust the balance during swimming (Iosilevskii \& Weihs, 2008). Red spotted grouper and seven-banded grouper has more dorsal soft rays, it considered that seven-banded grouper more carnivorous fish and fast swimming (Iosilevskii \& Weihs, 2008).

The diversely classified the stock identification, above all determining the vertebrae and swim bladder was regarded as efficient method among populations of fishes (Ford, 1937; Bailey \& Gosline, 1955; Chang \& Magnuson, 1968; Grandadeiro \& Silva, 2000). Results of total number of vertebrae were not found significant difference, 3 species have similar vertebrae (24 25), however difference of curved vertebral column was observed by dotted line/SL. Most curved vertebral column caused different size of swim bladder, it attributed to make the different velocity of water flow (Denton \& Marshall, 1958).

Different size of swim bladder influenced to the feeding habit, inhabitation and swimming velocity. Kelp grouper had a big volume of the swim bladder, thus it has a slower swimming velocity than other fish and less carnivorous fish and seven banded grouper has the fastest swim speed (Denton \& Marshall, 1958). Composition of dentary and anguloarticular attributed to feeding habit, kelp grouper has relatively less developed mandible, therefore kelp grouper eats tiny fish and cuttlefish (Brais, 1987).

Even though we studied Serranidae fishes are adequately distinguished from external color, there were some important information concerning overall body structure and internal organ. So far studied morphological classification is univariately investigated and simple decomposition of shape. Multivariate comparison, geometric truss dimension and sophisticated delineation methods were induced. Through many studies and research, we need for reliable research in morphological study and expected to various applications appearance.

\section{ACKNOWLEDGEMENTS}

This research was supported by a research grant (R2016038) from Future Aquaculture Research Center, National Fisheries Research and Development Institute, Korea. Comments from anonymous editors greatly improved the quality of this manuscript. We appreciate for research opportunity in this study and comply with the Current Laws of Korea (Ordinance of Agriculture, Food and Fisheries, No. 1- the Law Regarding Experimental Animals, No. 9932) and the Ethical Guidelines of Korea Maritime and Ocean University, Korea.

\section{REFERENCES}

Bailey RM, Gosline WA, (1955) Variation and systematic significance of vertebral counts in the American fishes of the family Percidae. Misc Publ Mus Zool Univ 93: $1-44$.

Barlow W (1961) Causes and significance of morphological variation in the fishes. Syst Zool 10:105-117.

Bookstein FL (1991) Morphometric tools for landmark data. Geometry and Biology. Cambridge Univ, p.512. 
Brais (1987) Grouper abstracts. SEAFDEC Aquacul Dept Tigbauan Iloilo Philippines, p.95.

Chang RKC, Magnuson JJ (1968) A radiographic method for determining gas bladder volume of fish. Copeia 1: 187-189.

Denton EJ, Marshall NB (1958) The buoyancy of bathypelagic fishes without a gas-filled swimbladder. J Mar Biol Ass UK 37:753-767.

Ford E (1937) Vertebral variation in teleostean fishes. J Mar Biol Ass UK 22:1-60.

Fukuhara O (1989) A review of the culture of grouper in Japan. Bull Nan Reg Fis Lab 22:47-57.

Grandadeiro JP, Silva MA (2000) The use of otoliths and vertebrae in the identification and size-estimation of fish in predator-prey studies. Cybium 24:383-393.

Heemstra PC, Randall JE (1993) Groupers of the world (Family Serranidae, Subfamily Epinephelinae). FAO Species Catalogue, no. 16.

Hurlbut T, Clay D (1998) Morphometric and meristic differrences between shallow- and deep water populations of white hake (Urophycis tenuis) in the Southern Gulf of St Lawrence. Can J Fish Aquatic Sci 55:2274-2282.

Ihssen PE, Booke HE, Casslman JM, McGlade JM, Payne NR, Utter FM (1981) Stock identification: materials and methods. Can J Fish Aquat Sci 38:1838-1855.

Iosilevskii G, Weihs D (2008) Speed limits on swimming of fishes and cetaceans. J R Soc Interface 5:329-338.

Kang JH, Yang SG, Moon TS, Park JY, Choi TJ (2013) Development of microsatellite markers for the kelp grouper Epinephelus bruneus. Gene Mole Res 12:54585493.

Kim BH, Kim KM, Lee YD, Song CB, Rho S (1997) Reproductive biology of the seven-banded grouper, Epinephelus septemfasciatus. I. The effect of HCG on ovulation induction. J Aquacult 10:55-61.

Li GL, Liu XC, Zhang Y, Bei JX, Lin HR (2004) Cloning and expression of two cytochrome P450 aromatase genes in red-spotted grouper, Epinephelus akaara. Acta Zool Sinica 50:791-799.

Lindsey CC (1988). Factors controlling meristic variation. Fish Physiol 11:197-274.

Melvin GD, Dadswell MJ, Mckenzie JA (1992) Usefulness of meristic and morphometric characters in discriminating populations of American shad (Alosa sapidissima) (Osteichthyes: Clupeidae) inhabiting a marine environment. Can J Fish Aquat Sci 49:266-280.

Nakamura T (2003) Meristic and mirphometric variations in fluvial Japanese charr between river systems and among tributaries of a river system. Enviro Biol Fish 66:133-144.

Park I-S, Kim BS, Kang EJ, Jang H (2012) Morphometric traits and cytogenetic analysis in induced cross and reciprocal hybrid between Rhodeus uyekii and R. notatus. Kor J Ichthyol 24:151-159.

Park I-S, Nam YK, Douglas SE, Johnson SC, Kim DS (2003) Genetic characterization morphometrics and gonad development of induced interspecific hybrids between yellowtail flounder, Pleuronectes ferrugineus (Storer) and winter flounder, Pleuronectes americanus (wlabaum). Aquacult Res 34:389-396.

Park I-S, Zhang CI, Lee YD (2001) Sexual dimorphism in morphometric characteristics of cocktail wrasse. J Fish Biol 58:1746-1749.

Park MO, Hur WJ, Lim S-Y, Seol D-W, Lee JW, Park I-S (2008) Anaesthetic efficacy and physiological responses to clove oil-anaesthetized kelp grouper, Epinephelus bruneus. Aquacult Res 39:877-884.

Saima A, Onkar SB (2015) Morphometric characters and meristic counts of a fish, Crossocheilus latius latius (hamilton-buchanan) from Ranjit Sagar Wetland, India. Int J Fish Stud 2:260-265.

Song YB, Baek HJ, Kim HB, Lee KJ, Kiyoshi S, Lee YD (2005) Induced sex reversal of sevenband grouper, Epinephelus septemfasciatus by $17 \alpha$-methyltestosterone. 
J Aquacult 18:167-172.

Song YB, Baek HJ, Kim HB, Soyano K, Kim SJ, Lee YD (2008) Induction of maturation and ovulation with hCG treatment in the sevenband grouper Epinephelus septemfasciatus. J Aquacult 21:96-101.

Straüss RE, Bond CE (1990) Taxonomic methods, morphology. Methods for Fish Biology, American Fish Society, Bethesda, MD, USA, 125-130.

Straüss RE, Bookstein FL (1982) The truss: body from reconstructions in morphometrics. Sys Zool 31:113-135.

Templeman W (1983) Stock discrimination in marine fishes. NAFO Sci Counc Stud 6:57-62.

Turan C, Oral M, Ozturk B, Duzunes E (2006) Morphometric and meristic variation between stocks of bluefish (Pomatomus saltatrix) in the Black, Marmara, Aegean and Northeastern Mediterranean seas. Fish Res 79:139-147.

Ukawa M, Higuchi M, Mito S (1966) Spawning habits and early life history of a serranid fish, Epinephelus akaara. Jpn J Ichtyl 13:156-161.

Videler JJ (1993) Fish kinematics: swimming movements stride by stride. Fish Swimming 6:113-137.

Yang MH, Choi YW, Jung MM, Ku HD, Oh BS, Moon TS, Lee CH, Kim KM, Han SJ (2007) Temperature effect in egg development and hatching of longtooth grouper, Epinephelus bruneus. Dev Reprod 11:105-109. 